\title{
Parathyroid Gland Oncocytic Adenoma
}

National Cancer Institute

\section{Source}

National Cancer Institute. Parathyroid Gland Oncocytic Adenoma. NCI Thesaurus. Code C27393.

A parathyroid gland adenoma composed predominantly or entirely of neoplastic cells with abundant granular eosinophilic cytoplasm. 